\title{
Investigation of Radionuclide Levels in Groundwater Around Transmission Company of Nigeria for Environmental Impact Assessment
}

\author{
Abiodun Odunlami Adegunwa ${ }^{1, *}$, Shola Hezekiah Awojide ${ }^{1}$, Odunayo Timothy Ore ${ }^{2}$ \\ ${ }^{1}$ Department of Pure and Applied Chemistry, Osun State University, Osogbo, Nigeria \\ ${ }^{2}$ Department of Chemistry, Obafemi Awolowo University, Ile-Ife, Nigeria \\ Email address: \\ abiodun.adegunwa@uniosun.edu.ng (A. O. Adegunwa) \\ ${ }^{*}$ Corresponding author \\ To cite this article: \\ Abiodun Odunlami Adegunwa, Shola Hezekiah Awojide, Odunayo Timothy Ore. Investigation of Radionuclide Levels in Groundwater \\ Around Transmission Company of Nigeria for Environmental Impact Assessment. Nuclear Science. Vol. 4, No. 4, 2019 , pp. 66-71. \\ doi: $10.11648 /$ j.ns.20190404.15
}

Received: November 9, 2019; Accepted: December 2, 2019; Published: December 11, 2019

\begin{abstract}
The activity concentrations of ${ }^{40} \mathrm{~K},{ }^{238} \mathrm{U}$ and ${ }^{232} \mathrm{Th}$ in groundwaters taken from areas surrounding Transmission Company of Nigeria, Osogbo, Nigeria were measured to highlight and ascertain possible radionuclide pollution. Highresolution gamma spectrometry (HPGe detector) was used to determine the activity concentration of these radionuclides and the results obtained were used to calculate human radiological risk by the inhabitants in the area. The activity concentrations of ${ }^{40} \mathrm{~K}$ in all the groundwater samples range from $53.48 \pm 2.90$ to $407.58 \pm 20.94 \mathrm{~Bq} / \mathrm{L}$. The activity concentrations of ${ }^{238} \mathrm{U}$ in the groundwaters range from BDL to $21.86 \pm 3.05 \mathrm{~Bq} / \mathrm{L}$. The activity concentrations of the ${ }^{232} \mathrm{Th}$ in the groundwaters range from $2.18 \pm 0.14$ to $11.76 \pm 0.68 \mathrm{~Bq} / \mathrm{L}$. Of the three investigated radionuclides, ${ }^{40} \mathrm{~K}$ was observed to have the highest mean activity concentration. The radiological parameters indicated mean values of $15.25 \mathrm{nGy} / \mathrm{hr}$ as the absorbed dose rate, $0.13 \mathrm{mSv} / \mathrm{yr}$ as the annual effective dose, $0.10 \mathrm{~Bq} / \mathrm{kg}$ as the internal hazard index, $0.08 \mathrm{~Bq} / \mathrm{L}$ as the external hazard index, $110.02 \mu \mathrm{svy}^{-1}$ as the annual gonadal dose equivalent, 0.24 as the representative gamma index and 31.11 as the radium equivalent. These suggested that the groundwaters do not pose intrinsic radiological hazards as a result of their relatively lower values than the UNSCEAR permissible levels. As a result of this, the occurrence of any heath effect due to radiation is low. These measurements therefore represent baseline values of these radionuclides in the ground waters of the studying area and further monitoring of these groundwaters should be encouraged.
\end{abstract}

Keywords: Activity Concentration, Gamma Index, Gamma Ray Spectrometer, Groundwater, Radiation

\section{Introduction}

Primordial radionuclides have existed since the creation of Earth and have been vital components of the environment. They are distinguished by their extreme long half-lives. These naturally occurring radioactivity materials disintegrate and emit ionizing radiation to the environment [1].

The concentration of radionuclide in an area however depends on the geological setting of the area. A review on the distribution of Uranium and thorium decay-series radionuclides in the environment has disclosed unequal distribution pattern due to different activities by man. Some works had been done in the use of sediments of Kubani River located at Zaria to establish possible pollution from industrial and human activities [2]. Distribution of long-lived radionuclides of the Uranium series in the Sediments of a small river in a Uranium mineralized region of Spain [3]. Radionuclide of uranium and thorium series in rain water over several tropical storms was studied [4]. Distribution of Uranium-Thorium nuclides in the riverine and coastal environments of the tropical southwest coast of India [5].

Radionuclides from the natural decay series are ubiquitous in the Earth's crust and because the radioactive constituents are soluble, plants and animals may uptake these elements into their bodies thereby constituting a source of environmental hazard when exceeding particular levels. 
The estimation of natural background emission in which Man is exposed to annually has been rated to be $1.1 \mathrm{mSv}$ [6].

Pollution of the environment by radionuclides and its isotopes even at low levels and the resulting long-term cumulative health effects are among the leading health concerns all over the world. In radioactivity research, attentions are most often given to gamma emitter's detection and quantification even in an environment where it is possible to have alpha and beta emitters [7]. Gamma rays have the highest penetrating power compared to alpha and beta particles within the body either through inhalation or ingestion, the effects of alpha and beta particles within the body are far more detrimental because of their ionizing power [8].

Groundwater is an important natural resource in Nigeria as it is the most widespread and highly used water resources. It flows through different bedrocks and are accumulated in fractures in the pore spaces of sand and gravel deposits. Groundwater quality can be endangered through leaching of radionuclides and their isotopes into underground aquifers by infiltrating natural water and contaminating drinking water cycle. The contribution of groundwater to total exposure to radionuclides is largely due to naturally occurring radionuclides in the uranium and thorium decay series and non-decay potassium series. The presence of radionuclides in water poses a number of health hazards, especially when these radionuclides are deposited in the human body through drinking. Dissolved radionuclides in water emit particles (alpha and beta) and photons (gamma) which gradually affect living tissues [9].

Increase in the level radioactivity of groundwater beyond tolerable limits could result into environmental degradation as well as several long-term health hazards like cancer, mental disorder, genetic mutation, etc., to workers and the general public [10].

Hence, the aim of the study is to determine the activity concentrations of natural radionuclide present in the groundwater consumed by the inhabitants and its possible radiological effects on the residents.

\section{Materials and Methods}

\subsection{Study Area}

The study area is the residential area around Transmission Company of Nigeria (Figure 1) in Osogbo, the capital of Osun State. Osogbo city is within the tropic rainforest zone in Nigeria and has a total land area of $500 \mathrm{~km}^{3}$ with estimated population of 156,694 . It is located on latitude $7^{\circ} 77^{\prime} 2$ ” $\mathrm{N}$ and longitude $4^{\circ} 56^{\circ} 36^{\prime \prime} \mathrm{E}$ with an elevation of $336 \mathrm{~m}$ above sea level.

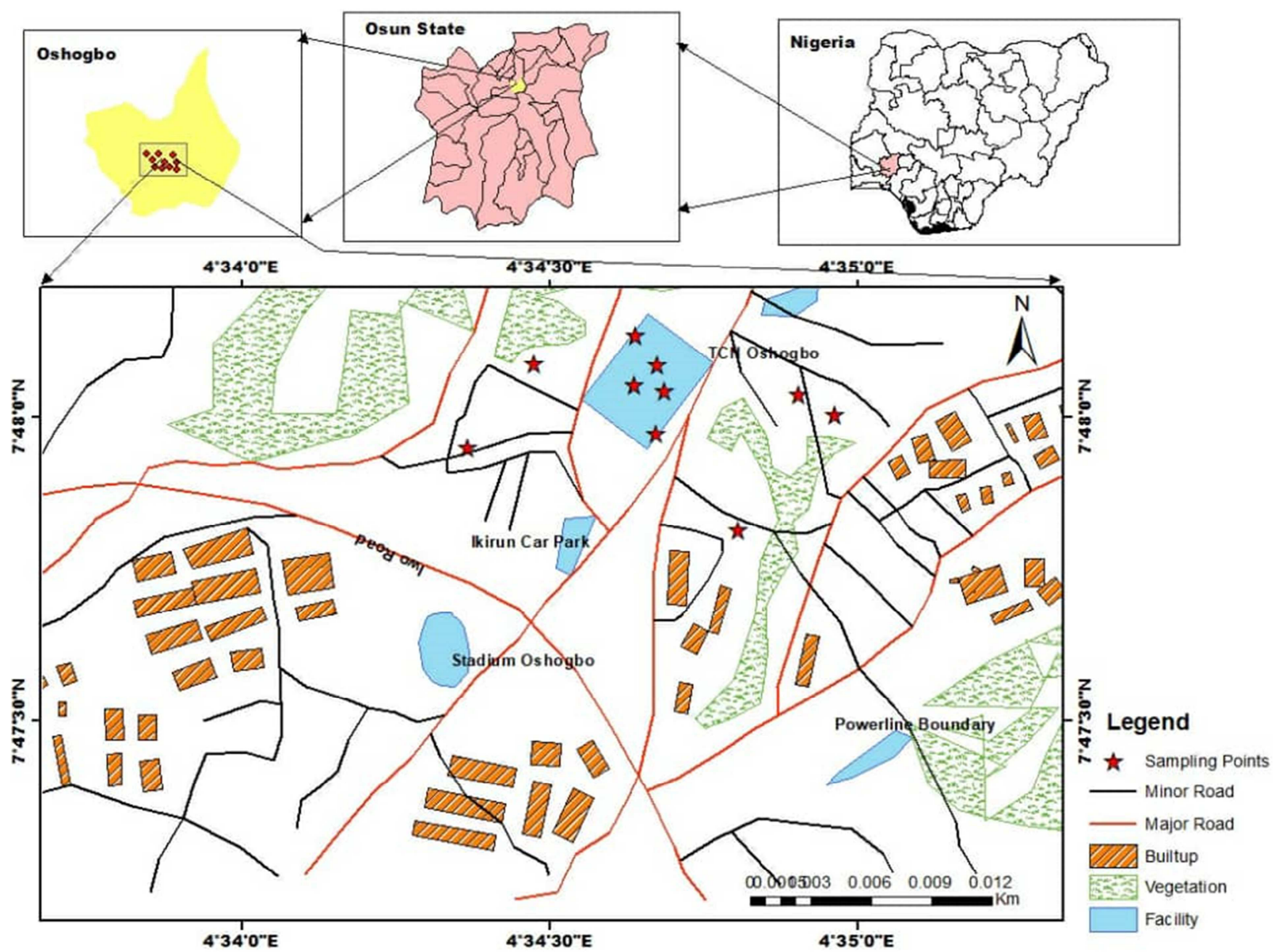

Figure 1. Map of the Study Area showing the Sampling Locations. 


\subsection{Sample Collection and Treatment}

A total of 10 groundwater samples from hand dug wells were collected from residential area around the power transmission company Osogbo, Nigeria. At each location, the water sample was poured into clean labeled polyethylene container and acidified with $11 \mathrm{M}$ of $\mathrm{H}_{3} \mathrm{O}^{+}, \mathrm{Cl}^{-}$at the rate of $10 \mathrm{ml}$ per liter of sample as soon as possible after sampling to avoid absorption of radionuclides on the walls of the containers [11, 12]. $250 \mathrm{ml}$ of each water sample was measured with measuring cylinder. The water samples were then transferred into uncontaminated empty cylindrical plastic containers of uniform size $(60 \mathrm{~mm}$ height by $65 \mathrm{~mm}$ diameter). The containers were sealed for about 28 days to allow ${ }^{222} \mathrm{Rn}$ and its short-lived progenies to reach secular equilibrium prior to gamma spectroscopy.

\subsection{Gamma Spectrometric Analysis}

The gamma ray spectrometry analysis was carried out at the National Institute of Radiation Protection and Research (NIRPR), University of Ibadan, Nigeria. This was done using a Canberra vertical HPGe detector of length $10 \mathrm{~cm}$ and diameter $10 \mathrm{~cm}$ with a relative efficiency of $20.2 \%$, enclosed in a lead shield of thickness $10 \mathrm{~cm}$. The complete electronic instrumentation was connected to a PC-based multichannel analyzer for gamma spectrum evaluation. The energy and efficiency calibration of the detector was carried out using the $1.33 \mathrm{MeV}$ gamma line of Co-60 resulting to energy resolution of $2.3 \mathrm{keV}$ (FWHM) with a relative yield of $1.73 \%$. Each sample was counted for a period of 18,000 s (5 h) and the gamma spectrum peak area analysis and quantification was carried out using the Genie 2000 software.

The specific activity of the radionuclide in each groundwater sample was calculated using the expression:

$$
C=\frac{A}{V \gamma T \varepsilon p}
$$

Where: $\mathrm{C}=$ Specific activity of the radionuclide in $\mathrm{BqL}^{-1}$

$\mathrm{A}=$ Net area count under the photopeak of each radionuclide
$\mathrm{V}=$ Volume of water sample

$\mathrm{T}=$ Counting time.

$\gamma=$ Gamma yield or absolute probability of the specific gamma ray.

$\varepsilon p=$ Efficiency at specific gamma-ray energy in $\mathrm{Bq} / \mathrm{L}$.

\subsection{Radiometric Measurements}

\subsubsection{Evaluation of Radium Equivalent $\left(R a_{e q}\right)$}

Radium equivalent activity $\left(\mathrm{Ra}_{\mathrm{eq}}\right)$ evaluates and predicts exposure to radiation to living organisms in terms of radiation dose. Radium equivalent activity is indexes that represent the specific activity of ${ }^{40} \mathrm{~K},{ }^{232} \mathrm{Th}$ and ${ }^{226} \mathrm{Ra}$ by a single quantity which takes into consideration the hazard of radiation associated with them.

The equation is given in $\mathrm{Bqkg}^{-1}$, the $\mathrm{Ra}_{\mathrm{eq}}$ expression is below:

$$
\mathrm{Ra}_{\mathrm{eq}}=0.077 \mathrm{~A}_{\mathrm{K}}+\mathrm{A}_{\mathrm{Ra}}+1.43 \mathrm{~A}_{\mathrm{Th}}
$$

This is an assumption that $4810 \mathrm{BqL}^{-1}$ of ${ }^{40} \mathrm{~K},{ }^{259} \mathrm{BqL}^{-1}$ of ${ }^{232} \mathrm{Th}$ and ${ }^{370} \mathrm{BqL}^{-1}$ of ${ }^{226} \mathrm{Ra}\left({ }^{238} \mathrm{U}\right)$ produce the same gamma dose.

\subsubsection{Absorbed Dose Rate (ADR)}

This measures the exposure to human body in order to determine the amount of radiological hazards. The absorbed dose rate at $1 \mathrm{~m}$ above the ground (in $\mathrm{nGyh}^{-1}$ by $\mathrm{BqL}^{-1}$ ) was calculated using the expression:

$$
\mathrm{ADR}=0.462 \mathrm{C}_{\mathrm{Ra}}+0.604 \mathrm{C}_{\mathrm{Th}}+0.0417 \mathrm{C}_{\mathrm{K}}\left(\mathrm{nGyh}^{-1}\right)
$$

where $\mathrm{C}_{\mathrm{Ra}}, \mathrm{C}_{\mathrm{Th}}$ and $\mathrm{C}_{\mathrm{K}}$ are the activity concentrations (Bqkg ${ }^{1}$ ) for ${ }^{226} \mathrm{Ra}$, ${ }^{232} \mathrm{Th}$ and ${ }^{40} \mathrm{~K}$ in groundwater samples, respectively.

\subsubsection{Annual Effective Dose Equivalent (AED)}

The mean annual evaluated effective dose equivalent (AED) taken by a person was figured out employing a transformation factor of $7 \times 10^{-1} \mathrm{SvGy}^{-1}$, which was used to transform the absorbed dose rate to humankind effective dose equivalent with an outdoor occupancy of $20 \%$ [7].

$$
\text { AED (outdoor) }(\mu \mathrm{Sv} / \mathrm{y})=\operatorname{ADR}\left(\mathrm{nGy} \mathrm{h}^{-1}\right) \times 0.7 \mathrm{~Sv} \mathrm{~Gy}^{-1} \times 8760 \text { hours } \times 0.2 \times 10^{-3}
$$

\subsubsection{Internal and External Hazard Index}

The internal exposure to ${ }^{222} \mathrm{Rn}$ and its hazardous progenies to the respiratory organs is controlled by the internal hazard index $\left(\mathrm{H}_{\mathrm{in}}\right)$ as described below [10]:

$$
\mathrm{H}_{\mathrm{in}}=\left(\mathrm{A}_{\mathrm{Ra}} / 185+\mathrm{A}_{\mathrm{Th}} / 259+\mathrm{A}_{\mathrm{K}} / 4810\right) \leq 1
$$

The $A_{R a}$ is replaced by $A_{U}$ in the calculations. It may be noted that ${ }^{238} \mathrm{U}$ is replaced by the decay product ${ }^{226} \mathrm{Ra}$, although there may be disequilibrium between ${ }^{238} \mathrm{U}$ and ${ }^{226} \mathrm{Ra}$. It is given as 1.03 by [13]. The factors which determine the exposure rate of an individual are the concentration of radionuclides in the groundwaters and the time spent outdoors [14]. A widely used hazard index reflecting external exposure called the external hazard index

$\mathrm{H}_{\mathrm{ex}}$ is defined as follows:

$$
\mathrm{H}_{\mathrm{ex}}=\left(\mathrm{A}_{\mathrm{Ra}} / 370+\mathrm{A}_{\mathrm{Th}} / 259+\mathrm{A}_{\mathrm{K}} / 4810\right) \leq 1
$$

\subsubsection{Annual Gonadal Dose Equivalent (AGDE)}

The gonads, the active bone marrow and the bone surface cells are considered as the organs of interest [10]. Therefore, the Annual Gonadal Dose Equivalent (AGDE) for the residents of the study area due to specific activities of ${ }^{226} \mathrm{Ra}$, ${ }^{232} \mathrm{Th}$ and ${ }^{40} \mathrm{~K}$ is calculated using the following relation [15]:

$$
\operatorname{AGDE}\left(\mu \mathrm{Svy}^{-1}\right)=3.09 \mathrm{~A}_{\mathrm{Ra}}+4.18 \mathrm{~A}_{\mathrm{Th}}+0.314 \mathrm{~A}_{\mathrm{K}}
$$

\subsubsection{Representative Gamma Level Index $\left(I_{\gamma r}\right)$}

The representative gamma radiation level index, $I_{\gamma r}$, is generally used to estimate the level of toxicity of 
radionuclides in the human body when there is exposure to a level of external annual effective doses of gamma radiations decayed from radioactive isotopes in environmental media. This additional hazard index also called radioactivity level index was calculated by using the formula below [16]:

$$
\mathrm{I}_{\gamma \mathrm{r}}=\mathrm{A}_{\mathrm{Ra}} / 150 \mathrm{BqL}^{-1}+\mathrm{A}_{\mathrm{Th}} / 100 \mathrm{BqL}^{-1}+\mathrm{A}_{\mathrm{K}} / 1500 \mathrm{BqL}^{-1}
$$

The value of $I_{\gamma \mathrm{r}}$ must be below 1 (unity) to keep the radiation hazard insignificant.

\section{Results and Discussion}

\subsection{Activity Concentrations of the Identified Radionuclides}

The activity concentrations of the identified radionuclides, ${ }^{40} \mathrm{~K},{ }^{238} \mathrm{U}$ and ${ }^{232} \mathrm{Th}$, in the groundwater samples and the control samples are presented in Tables 1 and 2 respectively. The mean activity concentrations of ${ }^{40} \mathrm{~K},{ }^{238} \mathrm{U}$ and ${ }^{232} \mathrm{Th}$ in the groundwater samples are $202.70 \pm 10.54,8.38 \pm 0.84$ and $6.45 \pm 0.38 \mathrm{~Bq} / \mathrm{L}$ respectively. The mean activity concentrations of the control samples are BDL (below detection limit), $11.96 \pm 1.61$ and $2.42 \pm 0.15 \mathrm{~Bq} / \mathrm{L}$ respectively. The mean activity concentrations of the identified radionuclides are higher in the groundwater samples than the control samples except for ${ }^{238} \mathrm{U}$. It is observed that ${ }^{40} \mathrm{~K}$ has the highest activity of the identified radionuclides. This may be due to the geological formations underlying the study area. This is consistent with the findings of Joel et al., 2019 [6]. Despite its relatively low isotopic abundance, ${ }^{40} \mathrm{~K}$ has been reported to be the principal naturally occurring source of internal radiation.

Table 1. Activity Concentrations of the Identified Radionuclides in the Water Samples $(B q / L)$.

\begin{tabular}{llll}
\hline Samples & ${ }^{\mathbf{4 0}} \mathbf{K}$ & ${ }^{\mathbf{2 3 8}} \mathbf{U}$ & ${ }^{\mathbf{2 3 2}} \mathbf{T h}$ \\
\hline W1 & $170.46 \pm 8.77$ & $12.36 \pm 1.28$ & $9.85 \pm 0.53$ \\
W2 & $53.48 \pm 2.90$ & $1.10 \pm 0.17$ & $6.48 \pm 0.40$ \\
W3 & $267.02 \pm 13.73$ & $10.34 \pm 1.06$ & $4.59 \pm 0.27$ \\
W4 & $348.41 \pm 17.91$ & $1.46 \pm 0.16$ & $11.76 \pm 0.68$ \\
W5 & $59.40 \pm 3.21$ & BDL & $2.18 \pm 0.14$ \\
W6 & $134.91 \pm 7.25$ & $21.86 \pm 3.05$ & $9.14 \pm 0.56$ \\
W7 & $180.39 \pm 9.67$ & BDL & $3.01 \pm 0.18$ \\
W8 & $407.58 \pm 20.94$ & $3.14 \pm 1.06$ & $4.59 \pm 0.27$ \\
Mean \pm SD & $202.70 \pm 10.54$ & $8.38 \pm 0.84$ & $6.45 \pm 0.38$ \\
\hline
\end{tabular}

$\mathrm{SD}=$ standard deviation, $\mathrm{BDL}=$ below detection limit
Table 2. Activity Concentrations of the Identified Radionuclides in the Control Samples $(B q / L)$.

\begin{tabular}{llll}
\hline Samples & ${ }^{\mathbf{4 0}} \mathbf{K}$ & ${ }^{238} \mathbf{U}$ & ${ }^{\mathbf{2 3 2}} \mathbf{T h}$ \\
\hline C1 & BDL & $11.96 \pm 1.61$ & $2.42 \pm 0.15$ \\
C2 & BDL & BDL & BDL \\
Mean \pm SD & BDL & $11.96 \pm 1.61$ & $2.42 \pm 0.15$ \\
\hline
\end{tabular}

$\mathrm{SD}=$ standard deviation, $\mathrm{BDL}=$ below detection limit

\subsection{Evaluation of the Radiological Impacts of the Groundwater Samples}

The radiological impacts of the groundwater samples in terms of the absorbed dose rate, the annual effective dose equivalent, internal hazard index, external hazard index, annual gonadal dose equivalent, and representative gamma index and radium equivalent are presented in Table 3 . The mean absorbed dose rate observed for the groundwater samples is $15.25 \mathrm{nGy} / \mathrm{hr}$. This is less than the population weighted average absorbed dose rate $(60 \mathrm{nGy} / \mathrm{hr})$ in outdoor air from terrestrial gamma radiation and that of the worldwide average of $55 \mathrm{nGy} / \mathrm{hr}$ [13]. The mean annual effective dose equivalent is $0.13 \mathrm{mSv} / \mathrm{yr}$ which falls lower than the range for individual countries $(0.3-0.6 \mathrm{mSv} / \mathrm{yr}$ range). World permissive annual dose limit is $1.0 \mathrm{mSv} / \mathrm{yr}$ [13]. The annual dose rate of the radionuclides in the groundwater samples is below the world permissive annual dose limit. This indicates that drinking the groundwaters may not lead to respiratory diseases such as asthma and cancer or external diseases such as erythema, skin cancer and cataracts. The internal hazard index is $0.10 \mathrm{~Bq} / \mathrm{L}$ while the external hazard index is $0.08 \mathrm{~Bq} / \mathrm{L}$. The values of the indices $\left(\mathrm{H}_{\mathrm{ex}}\right.$, $\mathrm{H}_{\text {in }}$ ) must be greater than 1.0 for the radiation hazard to be significant. The internal hazard and external hazard indices of the investigated ground waters are both less than 1 and so, the radiation hazard is insignificant. The mean annual gonadal dose equivalent of the radionuclides is $110.02 \mu \mathrm{Svy}^{-}$ ${ }^{1}$. This value is less than the world average of $300 \mu \mathrm{Svy}^{-1}$ [13]. The mean representative gamma index value of the groundwaters is 0.24 . This value is less than unity and this suggests that the water samples exhibit low gamma radiation. The estimated mean value of the $\mathrm{Ra}_{\mathrm{eq}}$ in this present study is $31.11 \mathrm{~Bq} / \mathrm{L}$. This value is lower than the world average of $370 \mathrm{~Bq} / \mathrm{L}$. The radiological impact assessment using the above parameters showed that the studied groundwaters exhibited low gamma radiation.

Table 3. Radiological Assessment of the Radionuclides in the Groundwater Samples.

\begin{tabular}{|c|c|c|c|c|c|c|c|}
\hline Samples & ADR (nGy/hr) & AED (mSv/yr) & $\mathrm{H}_{\text {in }}(\mathrm{Bq} / \mathrm{L})$ & $\mathrm{H}_{\mathrm{ex}}(\mathrm{Bq} / \mathrm{L})$ & AGDE $\left(\mu s v y^{-1}\right)$ & $\mathbf{I}_{\gamma \mathrm{r}}$ & $\mathbf{R} \mathbf{a}_{\mathrm{eq}}$ \\
\hline W1 & 18.76 & 0.16 & 0.14 & 0.10 & 132.88 & 0.29 & 39.57 \\
\hline W2 & 6.65 & 0.05 & 0.04 & 0.03 & 47.27 & 0.10 & 14.48 \\
\hline W3 & 18.68 & 0.16 & 0.12 & 0.10 & 134.98 & 0.29 & 37.46 \\
\hline W4 & 22.30 & 0.19 & 0.12 & 0.12 & 163.06 & 0.35 & 45.10 \\
\hline W5 & 3.79 & 0.03 & 0.02 & 0.02 & 27.76 & 0.06 & 7.69 \\
\hline W6 & 21.24 & 0.18 & 0.18 & 0.12 & 148.11 & 0.32 & 45.31 \\
\hline W7 & 9.34 & 0.08 & 0.04 & 0.04 & 69.22 & 0.15 & 18.19 \\
\hline Mean $\pm \mathrm{SD}$ & 15.25 & 0.13 & 0.10 & 0.08 & 110.02 & 0.24 & 31.11 \\
\hline
\end{tabular}

$\mathrm{SD}=$ standard deviation 


\subsection{Comparison of the Activity Concentrations with Similar Studies}

The activity concentrations of the investigated groundwaters in this study were compared with similar studies and the comparison is presented in Table 4. The identified radionuclides in this study $\left({ }^{40} \mathrm{~K},{ }^{238} \mathrm{U}\right.$ and $\left.{ }^{232} \mathrm{Th}\right)$ are all greater than the ones reported in the Radioactivity in some sachet drinking water samples produced in Nigeria by Ajayi and Adesida 2009 [17], Determination of natural radioactivity in groundwater in Tanke-Ilorin, Nigeria by Nwankwo 2013 [18], and Determination of Radioactivity Levels, Hazard, Cancer Risk and Radon Concentrations of Water and Sediment Samples in Al-Husseiniya River (Karbala, Iraq) by Al-Alawy et al. 2018 [19]. Relatively, ${ }^{40} \mathrm{~K}$ was higher in this study than the other studies by at least ten times. This could be due to the geological formation of the present study area.

Table 4. Comparison of the Activity Concentrations of this Study with Similar Studies.

\begin{tabular}{lllll}
\hline Radionuclides & This study & {$[\mathbf{1 7}]$} & {$[\mathbf{1 8}]$} & {$[\mathbf{1 9 ]}$} \\
\hline${ }^{40} \mathrm{~K}$ & 202.70 & 19.09 & NDT & 10.08 \\
${ }^{238} \mathrm{U}$ & 8.38 & 7.75 & 3.70 & 1.90 \\
${ }^{232} \mathrm{Th}$ & 6.45 & 2.03 & 3.60 & 1.23 \\
\hline
\end{tabular}

NDT $=$ not determined

\section{Conclusion}

The activity concentrations of ${ }^{40} \mathrm{~K},{ }^{238} \mathrm{U}$ and ${ }^{232} \mathrm{Th}$ in groundwater samples obtained around Transmission Company of Nigeria from eight (8) different sources in Osogbo, Nigeria were analyzed for their radionuclide levels, their activity concentrations and their radiological impacts to check the compliance with national and international regulation and obtain the data which can be used as a baseline for ascertaining possible changes in environmental radioactivity due to anthropogenic activities. This is the first detailed study of the natural radionuclide levels in the groundwater samples in Osogbo city of Nigeria. The radiological assessments of the detected radionuclides measured in the study are lower than permissible levels recommended by UNSCEAR. Nevertheless, further studies on the activity concentrations of the radionuclides in the groundwaters are encouraged.

\section{References}

[1] Faure, G., Mensing, T. M., 2005. Isotopes. Principles and Applications, third ed. John Wiley \& Sons, p. 897.

[2] Ewa, I. O. B., Oladipo, M. O. A. and Seydou H. (2004). Determination of Heavy elements in Nigerian River Sediments using the Energy Disperse X-Ray Flourescence Technique. Nigeria. Journal of Physics 16, 2.

[3] Lozano, J. C. P. Blanco Rodriguez, Vera Tome F. (2002). Distribution of long-live radionuclide of the Uranium -238 series in the sediment of a small River in a Uranium
Mineralized Region of Spain. Journal of Environmental Radioactivity, Vol. 63, issue 2, Pp 153.

[4] Martin P. (2003). Uranium and Thorium Series radionuclides in rainwater over several Tropical storms: Journal of Environmental Radioactivity Vol. 65, pp 1-18.

[5] Mehade M. H., M. I. Ali, D. Paul, M. A. Haydar, S. M. A. Islam (2014). Natural radioactivity and assessment of associated radiation hazards in soil and water samples collected from and around Barapukoria 2X125MW coal fired thermal power plant, Dinajpur, Bangladesh. Journal of Nuclear \& Particle Physics, 4 (1): 17-24, 10.5923/j.jnpp.20140401.03.

[6] Joel, E. S., Maxwell, O., Adewoyin, O. O., Olawole, O. C., Arijaje, T. E., Embong, Z., \& Saeed, M. A. (2019). Investigation of natural environmental radioactivity concentration in soil of coastaline area of Ado-Odo/Ota Nigeria and its radiological implications. Scientific Reports, 9 (1). doi: 10.1038/s41598-019-40884-0.

[7] Udousoro, I. I., I. U. Umoren, and E. O. Asuquo. 2010. Survey of some heavy metal concentrations in selected soils in South Eastern parts of Nigeria. World Journal of Applied Science and Technology 2 (2): 139-14.

[8] Gruber, V., Maringer, F. J., \& Landstetter, C. (2009). Radon and other natural radionuclides in drinking water in Austria: Measurement and assessment. Applied Radiation and

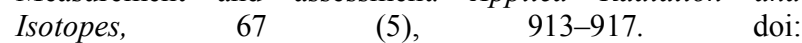
10.1016/j.apradiso.2009.01.056.

[9] Bello, I. A., Zakari, Y. I., Garba, N. N., Vatsa, A. M. and Kure, N. (2018). Radioactivity Level in Water around a Cement Factory in North Central Nigeria. Science World Journal. 13 (1)

[10] Avwiri, G. O., and O. E. Esi. 2015. Survey of background ionization radiation level in some selected automobile mechanic workshops in Uvwie LGA Delta State, Nigeria. Journal of Environment and Earth Science. (22): 56-60.

[11] International Atomic Energy Agency (1986). Summary Report on the post accident review meeting on the Chernobyl accident. Safety Ser. 75- INSAG-1, IAEA, Vienna.

[12] Lydie R. M. and Nemba R. M., (2008). Quantitative determination of 226Ra and 228Ra in reservoir and tap water in Yaoundé area, Cameroon. Glob. J. envir. Res. 2 (3): 110-113.

[13] United Nations Scientific Committee on the Effects of Atomic Radiation (UNSCEAR). 2000. Sources and effects of ionizing radiation. Report to the General Assembly. New York: United Nation.

[14] Avwiri, G. O., and C. P. Ononugbo. 2012. Natural radioactivity levels in surface soil of Ogba/Egbema/Ndoni Oil and Gas Fields. Energy, Science and Technology. 4 (2): 92101.

[15] Arafa, W. 2004. Specific activity and hazards of granite samples collected from the Eastern desert of Egypt. Journal of Environmental Radioactivity. 75: 315-22. doi: 10.1016/j.jenvrad.2004.01.004.

[16] Tufail, M., A. Nasim, and M. Waqas. 2006. Measurement of terrestrial radiation for assessment of gamma dose from cultivated and barren saline soils of Faisalabad in Pakistan in Radiation Measurement. Radiation Measurements 41: 443-51. doi: 10.1016/j.radmeas.2005.10.007. 
[17] Ajayi O. S. and Adesida G. 2009. Radioactivity in some sachet drinking water samples produced in Nigeria. Iran. J. Radiat. Res., 7 (3): 151-158.

[18] Nwankwo, L. I. 2013. Determination of natural radioactivity in groundwater in Tanke-Ilorin, Nigeria. West African Journal of Applied Ecology, vol. 21 (1): 111-119.
[19] Al-Alawy I. T., Mohammed R. S., Fadhil H. R., Hasan A. A. 2018. Determination of Radioactivity Levels, Hazard, Cancer Risk and Radon Concentrations of Water and Sediment Samples in Al-Husseiniya River (Karbala, Iraq). IOP Conf. Series: Journal of Physics: Conf. Series 1032 (2018) 012012 doi: 10.1088/1742-6596/1032/1/012012. 